\title{
Geoecological situation in coastal and sea area of the Western Yamal
}

\author{
Roy Shirokov ${ }^{1,2}$ \\ ${ }^{1}$ Earth Cryosphere Institute, Tyumen Scientific Centre SB RAS, 86, Malygina str., box 1230, \\ Tyumen, 625000, Russia \\ ${ }^{2}$ State University of Land Use Planning, 125315, 14, Baltiyskaya st, Russia
}

\begin{abstract}
An urgent problem is climate change and marine conditions affecting the formation and evolution of the permafrost zone of the shelf and the continental border of the Russian Arctic. The results of long-term monitoring of the permafrost zone clearly demonstrate the degradation of frozen rocks in both continental and subaquatic conditions of the western sector of the Russian Arctic. The coastal-marine region of Western Yamal is the most vulnerable and therefore model territory with climatic changes. Against the background of the observed climate dynamics, the study of geoecological processes becomes especially relevant when drawing up long-term plans for the development of climate-dependent branches of economic activity.
\end{abstract}

\section{Introduction}

Assessment of changes in geo-ecological conditions in the Arctic during climate warming and industrial development in recent decades has advanced several priority problems. Changes in climatic conditions affecting permafrost, sea hydrology, as well as the potential increase in negative anthropogenic pressures associated with growth, oil and gas production in the Arctic and the development of related infrastructure, sharply increase the level of geoecological risks. Climate warming and changing environmental conditions are changing the geo-ecological and land-use conditions.

A set of studies, including climatic and marine hydrological observations, morphology and landscape structure, permafrost dynamics and adverse cryogenic processes, is carried out on the western coast of the Yamal Peninsula near the Marre-Sale polar station. The territory was chosen as a model since all the features of the natural environment are present and manifest here. In the Marre Sale region, the main morphological levels are presented the third sea terrace, low and high river floodplains, modern low accumulative formations (sea laids). The territory belongs to typical tundra with a full set of characteristic plant communities. Permanent permafrost rocks are widespread. The characteristic features of land use are the combination of the traditional way of life of indigenous peoples and industrial oil and gas development in one territory.

Against the background of the observed climate dynamics, the study of geoecological processes becomes especially relevant when drawing up long-term plans for the development of climate-dependent branches of economic activity. 
Changes in climatic conditions affect the socio-economic activity of the regions, living conditions of people and public health; leads to changes in the natural environment and is reflected in the species composition of flora and fauna, river levels, weather conditions, seasonal rhythm, thawing of permafrost, the spread of areas of natural focal diseases, etc. Everything can entail the creation of a fire hazard and the possibility of environmental disasters. Climate change can have both positive and negative consequences.

The coastal-marine region of Western Yamal is the most model and vulnerable area under climatic changes. The geographical position of the seacoast is determined by the position of the border of the sea and the land, called the coastline or water edge. Moving the coastline towards the land causes the destruction and retreat of the coast, the corresponding movement of the entire coastal zone and a decrease in the land area. Moving the coastline in the opposite direction causes an increase in land area and the corresponding movement of the coastal zone.

\section{Objects of study}

The coastal-marine region of Western Yamal is the most model and vulnerable area under climatic changes. The geographical position of the seacoast is determined by the position of the border of the sea and the land, called the coastline or water edge. Moving the coastline towards the land causes the destruction and retreat of the coast, the corresponding movement of the entire coastal zone and a decrease in the land area. Moving the coastline in the opposite direction causes an increase in land area and the corresponding movement of the coastal zone.

Most of the Yamal Peninsula is occupied by lowland plains and does not rise above 50$60 \mathrm{~m}$ above the Kara Sea. Its flat surface is composed of upper Quaternary marine sediments and is dissected by shallow valleys of small tundra rivers starting from the lakes of the interior of the peninsula. The territory is heavily grained. The main role in the geological structure of Western Yamal is played by the Late Quaternary deposits of marine genesis, which form terraces of different heights in the relief $[2,3]$.

Based on long-term data of meteorological observations, it has been established that, since the 1970s. in the Arctic as a whole and in Western Yamal pronounced warming is observed. It occurs synchronously for the entire region of the Western Arctic, while not monotonously, but with some short-term fluctuations both in the direction of increasing and decreasing average annual temperature. Our data on the trends in average annual air temperature show that over the past 50 years, a moderate scenario of climate warming has been implemented in Western Yamal with an increase in average annual temperatures up to 4.0-4.5 ${ }^{\circ} \mathrm{C} / 100$ years [4].

Analysis of climatic data showed that an increase in the duration of the warm period is observed for Western Yamal. Autumn temperature transition through " 0 " is shifting to ever later dates. In recent years, this date has shifted from October 5 (1980) to October 17 (2016), which is about two weeks over the past 30-35 years. Climate warming is accompanied by an increase in annual precipitation. In the late 1960s and early 1970s. the amount of summer rainfall was $110-130 \mathrm{~mm}$, and by 2015 it had grown to $150-170 \mathrm{~mm}$. According to available observations, an increase in the maximum snow depth is observed: from $16 \mathrm{~cm}$ (statistically) in 1960 to $37 \mathrm{~cm}$ with a slight decrease in its density. Thus, the insulating role of snow has significantly increased.

It was noted that against the backdrop of global warming of the World Ocean, estimated at about $0.02-0.04{ }^{\circ} \mathrm{C}$ per year, the temperature of the bottom layer of water in the Kara Sea over the past 100 years has been increasing at a rate of from $0.01^{\circ} \mathrm{C}$ to $0.028^{\circ} \mathrm{C}$ per year [5]. This leads to accelerated degradation of subaquatic permafrost, additional methane 
emission from frozen rocks into the water column and accelerated biogeochemical processes.

An increase in air temperature, an increase in the duration of the ice-free period causes an increase in the average annual water temperature in the shallow area. Based on the results of measuring the thickness of seasonal (fast ice) ice for 1998-2018. we can conclude that climate warming affects the ice cover to the greatest extent. In West Yamal, the maximum thickness of seasonal ice over the past 20 years has decreased (statistically) from 150 to $115 \mathrm{~cm}$. The temperature of permafrost in the continental region rises due to climate warming. From 1978 to 2018 , on average in the research area, the average annual temperature increased from -6.8 to $-4.6^{\circ} \mathrm{C}$. Due to climate warming in this zone, there is difficulty in permafrost neoplasm and its stability is violated [5].

Soil temperature plays a very important role in the development of soil processes and vegetation. In recent decades, a distinct trend has been forming in increasing the average annual temperature of the root layer of the soil (to a depth of $1.0 \mathrm{~m}$ ) from -7.5 to $-5.5 \ldots-6.0$ ${ }^{\circ} \mathrm{C}$. Thus, more favorable conditions are formed for the development of vegetation cover and biomass growth. Over the period from 1978 to 2018, on average in all dominant landscapes, the depth of seasonal thawing increased by $5-15 \%$. There is a progressive thawing of the upper horizon of frozen rocks and the development of destructive processes, primarily thermokarst.

Climate: Air temperature. Based on long-term data of meteorological observations, it has been established that, since the 1970s. in the Arctic as a whole and in Western Yamal pronounced warming is observed. It occurs synchronously for the entire region of the Western Arctic, while not monotonously, but with some short-term fluctuations both in the direction of increasing and decreasing average annual temperature. In general, the gradient of the increase in average annual temperature for 1970-2018. amounted to about $2.2^{\circ} \mathrm{C}$, i.e. $0.04{ }^{\circ} \mathrm{C} /$ year. These are high values of the temperature rise gradient. There is no evidence that such rates of climate warming will continue in the future [4].

In recent decades, it is customary to predict climate changes based on the family (ensemble) of climate models [1], each of which has its own set of advantages and disadvantages. Data analysis using a family of models allows to some extent to level out their individual flaws and get more reliable estimates. Our data on the trends in average annual air temperature show that over the past 50 years a moderate but approaching a "tough" scenario of climate warming has been implemented in Western Yamal with an increase in average annual temperatures to $4.0-5.5^{\circ} \mathrm{C} / 100$ years. The catastrophic scenario provides for a temperature increase of $6^{\circ} \mathrm{C} / 100$ years or more, an acceptable level that does not cause irreversible changes is considered to be a warming level of $2{ }^{\circ} \mathrm{C} /$ 100 years $[1,5]$. An increase in the number of air temperature anomalies during climate warming has not been established. The duration of the warm period. Analysis of climatic data for the Marre-Sale polar station shows that an increase in the duration of the warm period is observed for the Western Yamal.

The transition of the daily temperature through " 0 " in the spring shifts to ever earlier dates, from June 19 to June 2 (along a linear trend). Autumn temperature transition through " 0 ", on the contrary, is shifting to ever later dates. In recent years, this date has shifted from October 9 (1980) to October 15 (2017). Thus, the duration of the warm period increased by about three weeks over the past 30-35 years.

Precipitation. Western Yamal belongs to the zone of excessive moisture. Climate warming is accompanied by an increase in annual precipitation, while the amount of winter precipitation increases to a slightly lesser extent than summer precipitation. The amount of summer rainfall has grown markedly. In the late 1960s and early 1970s the amount of summer rainfall was $110-130 \mathrm{~mm}$, and by 2015 it had grown to $150-170 \mathrm{~mm}$. 
Snow cover. According to available observational data, an increase in the maximum snow cover is observed. From $16 \mathrm{~cm}$ (statistically) in 1960, the height of the snow cover increased to $37 \mathrm{~cm}$, with a slight decrease in its density. Thus, the insulating role of snow has significantly increased.

Hydrology of the sea. Bottom water temperature on the high seas. An analysis of the observations showed that against the backdrop of global warming of the World Ocean, estimated at about $0.02-0.04{ }^{\circ} \mathrm{C}$ per year [4], the temperature of the bottom layer of water in the Kara Sea over the past 100 years, depending on the morphological and structural features of the marine bottom and heat transfer conditions, including The flow of warm Atlantic waters through the Kara Gates and Matochkin Shar straits rises at a rate of $0.01{ }^{\circ} \mathrm{C}$ per year (North Taimyr shelf) to $0.028^{\circ} \mathrm{C}$ per year (Baydaratskaya Bay). This leads to accelerated degradation of subaquatic permafrost, additional methane emission from frozen rocks into the water column and accelerated biogeochemical processes.

Water temperature in shallow water. An increase in air temperature, an increase in the length of the ice-free period causes an increase in the average annual water temperature in a shallow area. Based on our observations, the rate of increase in water temperature here is estimated at $0.03-0.035^{\circ} \mathrm{C} /$ year, which exceeds the maximum observed increase in the temperature of the bottom layer of water in the open sea. In other words, the reaction of the shallow zone of the Kara Sea to climate change is more acute than at great depths. Instrumental measurements in shallow water made it possible to establish that rapid changes (hours and the first day) of the bottom water temperature under conditions of prevailing sea waves up to $0.5 \mathrm{~m}$ occur only at sea depths less than $6 \mathrm{~m}$. At greater depths, the temperature of the bottom water layer changes due to longer-term changes air temperature - seasonal and interannual changes. Based on general ideas about the laws of mixing of water masses in the sea under wind waves [6] and a predominant wave height of $0.5-1 \mathrm{~m}$, it can be stated that for the Kara Sea, the outer shallow boundary is limited to 6$10 \mathrm{~m}$ isobath. It is interesting to note that on at the same depths is the outer boundary of the coastal talik in subaquatic frozen rocks.

Wind waves and storms. An analysis of the available data shows the immutability of wind wave parameters and the frequency and strength of storms over time against a changing climate. The literature contains satellite altimetry data, according to which an insignificant but steady increase in the height of wind waves and the frequency of storms has been observed for 23 years [7]. The growth rates are so small that on a time scale of 10-100 years, the parameters of waves and storms can be considered unchanged.

Seasonal ice cover (fast ice) and freezing zone. Based on the results of measuring the thickness of seasonal (fast ice) ice for 1998-2018. we can conclude that climate warming affects the ice cover to the greatest extent. In West Yamal, the maximum thickness of seasonal ice over the past 20 years has decreased (statistically) from 150 to $115 \mathrm{~cm}$. The width of the freezing band (seasonal habitat of marine biota) along the accumulative coasts has decreased from 150-170 $\mathrm{m}$ to $90-120 \mathrm{~m}$. On thermoabrasive shores this the decrease was from $80-130 \mathrm{~m}$ to $60-90 \mathrm{~m}$. Even more striking changes are observed in changes in the area of sea ice, but they are not considered here.

Geological environment: Climatic changes do not affect the composition of frozen deposits; therefore, they are not considered here. The temperature of frozen rocks on the third sea terrace. The temperature of permafrost rocks (MMP) in the continental region rises due to climate warming. From 1978 to 2018 the average annual temperature in the study area increased from -6.8 to $-4.6^{\circ} \mathrm{C}$. In all zonal landscapes of a typical tundra, the increase in average annual temperature is approximately the same. In azonal landscapes swamps and peatlands - the temperature increase is not the same: swamps are characterized by a maximum change in average annual temperature, peatlands - by a minimum. That is, different landscapes have different reactions to climate change. 
The temperature of frozen rocks in the transition region depends on the type of lithodynamic processes. On the beaches near thermo-abrasive shores, there is such a high increase in average annual temperature that here we can talk about the transition of the upper stratum of frozen rocks to a seasonally frozen state. Observations in wells located in this type of transition region showed that the average annual temperature varies between $0.9 \ldots-2.0^{\circ} \mathrm{C}$, i.e. most often, it is higher than the temperature of phase transitions $\left(-1.4^{\circ}\right.$ C) [6]. Thus, during the transition from the continental type of cryogenic strata to transit, a sharp jump in the average annual temperature from $-4.5 \div-6.5^{\circ} \mathrm{C}$ to $-0.9 \div-2.1^{\circ} \mathrm{C}$ is observed. In the area of marine accumulation, the formation of low accumulative islands is observed, and permafrost is newly formed in syngenetic type. The average annual temperature of rocks increased from -4.4 to $-3.5^{\circ} \mathrm{C}$. Due to climate warming in this zone, there is a difficulty in permafrost neoplasm and its stability is violated [5]. Within the river floodplain, an increase in permafrost temperature led to thawing of permafrost from above and the formation of through-hole taliks with a depth of up to $2.7 \mathrm{~m}$, which had not previously been formed. The average annual temperature of frozen rocks on such landscapes increased to $-0.25 \ldots+0.5^{\circ} \mathrm{C}$.

Soil temperature plays a very important role in the development of soil processes and vegetation. Our observations have shown that in recent decades a distinct trend has been formed in increasing the average annual temperature of the root layer of the soil (to a depth of $1.0 \mathrm{~m}$ ) from -7.5 to $-5.5 \ldots-6.0^{\circ} \mathrm{C}$. Thus, more favorable conditions are formed for the development of vegetation cover and biomass growth.

Depth of seasonal thawing. The depth of seasonal thawing is the most important indicator of the response of permafrost landscapes to climate change and an indicator that determines the development of soil processes and the conditions of root habitat of the vegetation cover. Over the period from 1978 to 2018, on average for all dominant landscapes, the depth of seasonal thawing increased by only $5-15 \%$. On this basis, some researchers consider the depth of seasonal thawing an unreliable indicator of the reaction of permafrost to climate change. MMP, as a cryogenic geosystem, has its own protection mechanisms against progressive thawing based on feedback from external factors. Thus, on the one hand, climate warming should cause an increase in the depth of seasonal thawing, on the other hand, protection mechanisms simultaneously work. As a result, an underestimated reaction of the depth of seasonal thawing to an increase in average summer air temperature is observed. All this relates to natural conditions. For any man-made violations of compensation, there is no additional heat influx, and progressive thawing of the upper horizon of frozen rocks and the development of destructive processes, primarily thermokarst, are observed.

Cryogenic processes. In the coastal-marine region, the main role in the formation of geo-ecological conditions belongs to coastal processes - the destruction of sea coasts or thermal abrasion, the reformation of the adjacent part of the underwater coastal slope, the processes of accumulation of marine sediment and the formation of marine accumulative forms, to a much lesser degree of wind deflation. Based on long-term monitoring of coastal dynamics, it was found that the retreat rate of thermo-abrasive coasts is not directly related to indicators of climate change but is determined by more complex relationships with the characteristics of atmospheric processes - baric circulation processes in the Arctic as a whole. The coastal retreat rate is characterized by extremely high spatial variability. The destruction of seacoasts is not constant over time but varies cyclically with a period of the order of 21-23 years. The average long-term coastal retreat rate in the study area is about $1.7 \mathrm{~m} /$ year, varying from $0.4 \mathrm{~m} /$ year to $3.2 \mathrm{~m} /$ year in different periods. These values should be used in the development of engineering solutions for the industrial development of the coastal-marine region of Western Yamal. 
Under natural conditions, the deformations of beaches and the underwater coastal slope are characterized by moderate values - up to $0.7 \mathrm{~m}$, usually even up to $0.10-0.15 \mathrm{~m}$. According to our observations, the deformation of the beaches and the adjoining part of the underwater coastal slope may have a different sign. But carrying out technical work in the abutment zone of the underwater coastal slope, artificial movement or selection of sediments sharply increase the activity of coastal processes. Using the example of the neighboring region of the Kharasey metro station, it is known that the selection of sand deposits in the coastal zone [6] led to a more than twofold increase in the rate of shore destruction [6]. The retreat of the seacoast is accompanied by the development of thermal denudation and linear erosion. Short ravines form along the polygonal vein ice with a speed of movement of the peaks of the ravines up to $10 \mathrm{~m} /$ year. Thermal denudation circuses with a length of up to 300 and more meters and a depth of incision towards the coast of up to $200 \mathrm{~m}$ are formed in the areas of development of massifs of formation ice. Deflation processes affect the strip of the coast up to 200-400 m wide.

Thus, the width of the risk zone of the coastal-marine region, due to the intensive development of cryogenic processes, is about $400 \mathrm{~m}$ from the coastal strip inland [5].

\section{Results and Discussion}

Analysis of the data obtained, their interpretation makes it possible to assess changes in the geoecological situation of the coastal-marine region of Western Yamal in a changing climate. Climatic changes entail a change in the hydrology of the Kara Sea and key indicators of permafrost conditions. All these characteristics of the environment cause changes in the geoecological conditions of a specific coastal-marine region, which is simultaneously affected by the sea and the continent. Changes occur in all components of the geoecological environment, but here we consider those that can be evaluated based on the data obtained. In most cases, the estimates are of a qualitative nature.

Vegetation cover and soil. Since plant communities in the area of a typical tundra live at the limit of survival, an increase in the average annual and average summer temperatures directly affects the species composition and the growth of bio-productivity of the vegetation cover. The shift in the timing of the transition of air temperature through " 0 " increases the duration of the growing season. An increase in the amount of summer rainfall in conditions of excess moisture leads to waterlogging of the territory, an increase in the share of bog plant communities and a decrease in the habitat of vegetation of drained tundra. The increase in the thickness of the snow cover favorably affects the tundra shrubs of willow (Salix polaris, S. glauca) and dwarf birch (Betula nana), since the snow cover is a natural protector of the branches of shrubs from frostbite. Over the past 30 years, the height of willow curtains has increased from $20-30$ to $40-50 \mathrm{~cm}$. An increase in permafrost and soil cover temperature causes an increase in the root habitat layer and a change in the structure of vegetation adapted to the frozen root substrate.

An increase in air temperature and an extension of the duration of the warm period favorably affects the speed of biogeochemical processes. An increase in the amount of summer precipitation causes waterlogging, waterlogging of the territory and the formation of marsh soils. The proportion of drained soils is declining. An increase in permafrost temperature is also accompanied by an increase in soil temperature. They become "warmer", the thickness of the soil cover increases. Soils of a typical tundra in the coastal marine region of Western Yamal are subject to wind erosion. The duration and strength of winds during climate warming does not change, so it should be expected that the intensity of wind erosion of soils will not increase.

The traditional way of life of the indigenous population. Climate warming most directly affects the traditional way of life of indigenous peoples, and they adapt to new conditions. 
Restructuring of the vegetation cover, shifting the forest border to the north cause a change in the structure of pastureland and a change in traditional nomadic routes. Changes in the terms and duration of the warm period also lead to a shift in the timing of driving reindeer herds, and in some cases to a change in the boundaries of pastures assigned to individual families and households. The increase in the maximum height of the snow cover makes it difficult for the deer to get food, but these difficulties are relatively small.

Climate warming and the resulting increase in the depth of seasonal thawing can cause a deterioration in the sanitary-epidemiological situation. An example is 2016, when, due to the threat of anthrax, quarantine was declared, and appropriate measures were taken throughout the territory of Yamal. In addition, our estimates show that the retreat of the coast leads to the loss of pasture quality land in the Yamalo-Nenets Autonomous Okrug with an area of about 140 hectares annually.

Industrial (oil and gas) development. Climate warming and the resulting changes in geoecological conditions have the greatest impact on the principles of industrial development, mainly the oil and gas complex. At the same time, changes in geo-ecological conditions, even without taking into account the technogenic load, must be taken into account when designing and at the stage of construction and operation of industrial facilities. Climate warming improves the climatic and structural characteristics, including an increase in the duration of the warm period for construction work, but at the same time, the terms for using winter roads (winter roads) are reduced by about two weeks. An increase in summer precipitation can complicate industrial development due to flooding and waterlogging, and an increase in the maximum snow cover leads to an increase in snow removal.

The established increase in the temperature of the bottom layer of water by $1-2.8^{\circ} \mathrm{C}$ over 100 years causes the degradation of subaqueous permafrost and the formation of uneven subsidence of the seabed with an amplitude of up to three meters, which complicates the construction of port facilities, sea channels, etc. As the results of studying the topography of the Kara Sea seabed at depths of up to $10 \mathrm{~m}$, the planned size of subsidence areas can reach the first hundred of meters. In the coastal region, due to the reduction in the width of the freezing zone of fast ice and the increase in water temperature in the coastal zone, active degradation and accelerated lowering of the permafrost roof are observed, and as a result, deformations of the foundations of coastal structures are possible and expected. The temperature of frozen rocks increased by $2^{\circ} \mathrm{C}$ from 1978 to 2018 . led to the loss of the bearing capacity of the pile foundations by about $20-25 \%[1,6]$.

In a generalized form, the influence of environmental factors on the formation of geoecological conditions is given in Table. 1 .

Table 1. Change of geoecological conditions of coastal and sea area the western Yamal when warming climate

\begin{tabular}{|c|c|c|c|c|}
\hline \multirow[b]{2}{*}{$\begin{array}{c}\text { The } \\
\text { environment } \\
\text { factors } \\
\text { influencing } \\
\text { geoecological } \\
\text { situation }\end{array}$} & \multicolumn{4}{|c|}{ Recipients } \\
\hline & Plant cover & Soils & $\begin{array}{c}\text { Traditional tenor of } \\
\text { life of indigenous } \\
\text { people }\end{array}$ & $\begin{array}{l}\text { Industrial (oil } \\
\text { and gas) } \\
\text { development }\end{array}$ \\
\hline \multicolumn{5}{|c|}{ Climate } \\
\hline $\begin{array}{c}\text { Air } \\
\text { temperature }\end{array}$ & $\begin{array}{l}\text { Change of species } \\
\text { composition of } \\
\text { vegetation. Shift } \\
\text { of borders of } \\
\text { bioclimatic zones } \\
\text { to the North. } \\
\text { Growth of } \\
\text { bioproductivity }\end{array}$ & $\begin{array}{l}\text { Accelerati } \\
\text { on of } \\
\text { biogeoche } \\
\text { mical } \\
\text { processes }\end{array}$ & $\begin{array}{l}\text { Change of structure of } \\
\text { pastures. } \\
\text { Change of traditional } \\
\text { nomadic routes }\end{array}$ & $\begin{array}{l}\text { Improvement of } \\
\text { construction } \\
\text { climatic index }\end{array}$ \\
\hline
\end{tabular}




\begin{tabular}{|c|c|c|c|c|}
\hline $\begin{array}{l}\text { Change of } \\
\text { duration of } \\
\text { the warm } \\
\text { period }\end{array}$ & $\begin{array}{c}\text { Increase in } \\
\text { duration of the } \\
\text { vegetative period }\end{array}$ & & $\begin{array}{l}\text { Shift of terms of stage } \\
\text { of cervine herds }\end{array}$ & $\begin{array}{l}\text { Increase in } \\
\text { duration of the } \\
\text { warm period. } \\
\text { Reduction of } \\
\text { terms of use of } \\
\text { winter roads }\end{array}$ \\
\hline $\begin{array}{l}\text { Summer } \\
\text { rainfall }\end{array}$ & $\begin{array}{c}\text { Increase in share } \\
\text { of marsh } \\
\text { landscapes }\end{array}$ & $\begin{array}{c}\text { Remoisten } \\
\text { ing and } \\
\text { bogging }\end{array}$ & & $\begin{array}{l}\text { Possibility of } \\
\text { flooding of } \\
\text { construction } \\
\text { objects } \\
\end{array}$ \\
\hline Snow & $\begin{array}{l}\text { Increase in gain of } \\
\text { bushes }\end{array}$ & & $\begin{array}{l}\text { Difficulties in getting } \\
\text { of forage deer }\end{array}$ & $\begin{array}{c}\text { Increase in } \\
\text { volumes of } \\
\text { snow removal }\end{array}$ \\
\hline \multicolumn{5}{|c|}{ Sea hydrology } \\
\hline $\begin{array}{c}\text { Benthonic } \\
\text { water } \\
\text { temperature } \\
\text { in high sea }\end{array}$ & & & & $\begin{array}{c}\text { Formation of } \\
\text { sags of sea floor } \\
\text { due to } \\
\text { degradation of } \\
\text { permafrost with } \\
\text { reservoir ices }\end{array}$ \\
\hline $\begin{array}{c}\text { Water } \\
\text { temperature } \\
\text { in coastal } \\
\text { area }\end{array}$ & & & & $\begin{array}{l}\text { Deformations of } \\
\text { the bases } \\
\text { (technology } \\
\text { objects) at the } \\
\text { expense of the } \\
\text { accelerated } \\
\text { degradation of } \\
\text { permafrost }\end{array}$ \\
\hline $\begin{array}{c}\text { Seasonal } \\
\text { (pripayny) ice }\end{array}$ & & & & $\begin{array}{l}\text { Narrowing of } \\
\text { strip of } \\
\text { adfreezing of } \\
\text { sea ice and sea } \\
\text { floor } \\
\end{array}$ \\
\hline \multicolumn{5}{|c|}{ Geologic environment } \\
\hline $\begin{array}{c}\text { MMP } \\
\text { temperature }\end{array}$ & $\begin{array}{c}\text { Change of } \\
\text { structure of plant } \\
\text { cover on frozen } \\
\text { substrate }\end{array}$ & $\begin{array}{c}\text { Temperat } \\
\text { ure } \\
\text { increase } \\
\text { of soils }\end{array}$ & & $\begin{array}{c}\text { Decrease in } \\
\text { bearing capacity } \\
\text { of the pile bases }\end{array}$ \\
\hline $\begin{array}{l}\text { Depth of } \\
\text { seasonal } \\
\text { thawing }\end{array}$ & $\begin{array}{l}\text { Increase in layer } \\
\text { of korneobitaniye }\end{array}$ & $\begin{array}{l}\text { Increase } \\
\text { in power } \\
\text { of soil } \\
\text { covering }\end{array}$ & $\begin{array}{l}\text { Possible deterioration } \\
\text { in sanitary and } \\
\text { epidemiologic } \\
\text { situation }\end{array}$ & $\begin{array}{l}\text { The accelerated } \\
\text { cryogenic } \\
\text { destruction of } \\
\text { headstalls of } \\
\text { piles }\end{array}$ \\
\hline $\begin{array}{l}\text { Cryogenic } \\
\text { processes }\end{array}$ & & $\begin{array}{c}\text { Wind } \\
\text { erosion of } \\
\text { soils }\end{array}$ & $\begin{array}{c}\text { Loss of pasturable } \\
\text { lands }\end{array}$ & $\begin{array}{l}\text { Development of } \\
\text { dangerous } \\
\text { processes at } \\
\text { technogenic } \\
\text { impact on } \\
\text { permafrost }\end{array}$ \\
\hline
\end{tabular}




\section{Conclusions}

Based on long-term monitoring (30 years) of coastal dynamics, it was found that the retreat rate of thermo-abrasive coasts is not directly related to indicators of climatic changes, but is determined by more complex relationships with the characteristics of atmospheric processes - baric circulation processes in the Arctic as a whole. The destruction of seacoasts is not constant over time but changes cyclically with a period of the order of 21-23 years. The average multi-year coastal retreat rate in the study area is about $1.7 \mathrm{~m} /$ year, varying from $0.4 \mathrm{~m} /$ year to $3.2 \mathrm{~m} /$ year in different periods. According to our observations, deformations of beaches and the adjoining part of the underwater coastal slope may have the opposite sign [6]. Thus, the width of the risk strip of the coastal-marine region, due to the intensive development of cryogenic processes, is about $400 \mathrm{~m}$ from the coastal strip inland.

The current unstable state of the Yamal geosystems is due to the geological, structural and geodynamic features of the territory, the history of its formation and development during the Pleistocene-Holocene time, and current trends in changes in natural and climatic conditions. Due to climate warming in this zone, there is a difficulty in the formation of permafrost and its stability is violated. Soil temperature plays a very important role in the development of soil processes and vegetation [7].

An analysis of the long-term monitoring data allows us to conclude that, within the coastal-marine region of Western Yamal, in a short space in its different natural zones, at the same time, there are reversible reactions (trends) of the components of the natural environment to climatic changes that determine the dynamics of the geo-ecological conditions of these zones.

Estimated climate change can have both positive and negative impacts. To consider the possible consequences of changing geo-ecological conditions of a territory, geographic forecasting, that is, a scientific study of specific prospects for the development of geographical phenomena, is of particular importance.

Overall, the geoecological conditions of the region can be considered quite stable so far, except for cases of industrial development, in which the anthropogenic load can exceed the adaptive capabilities of the natural environment.

The research of conditions and parameters of degradation of permafrost breeds is executed with assistance of the Russian Federal Property Fund, grant No. 18-05-60004, the assessment of change of geoecological conditions is carried out with assistance of grant of the Russian Federal Property Fund 19-35-90049.

\section{References}

1. IPCC. 2018: Summary for Policymakers. In: Global warming of $1.5{ }^{\circ}$ C. An IPCC Special Report on the impacts of global warming of $1.5^{\circ} \mathrm{C}$ above pre-industrial levels and related global greenhouse gas emission pathways, in the context of strengthening the global response to the threat of climate change, sustainable development, and efforts to eradicate poverty (World Meteorological Organization, Geneva, Switzerland, 2018).

2. V.N. Gataulin, Verkhnechetvertichnye of adjournment of the west bank of the Yamal Peninsula: abstract. yew. ... edging. geol. - the miner. Sciences, (Leningrad, 1988) (in Russian).

3. V.T. Trofimov, Yu.B. Badu, V.G. Kudryashov, N.G. Firsov, Yamal Peninsula (engineering-geological sketch) (Moscow university, Moscow, 1975) (in Russian). 
4. J. K. Willis, D. Roemmich, \& B. Cornuelle, J. of Geophysical Research: Oceans, 109, 12 (2004).

5. R. S. Shirokov \& A. A. Vasiliev, Natural Resource Management, GIS \& Remote Sensing, 1(1), 21-27 (2019).

6. A.A. Vasilyev, G.E. Oblogov, I.D. Streletskaya, R.S. Shirokov, Kriosfera Zemli, 12(5), 36 (2018) (in Russian).

7. The report "About strategic estimates of effects of climate changes in the next 10-20 years for the environment and economy of the Union State", considered at meeting of Council of ministers of the Union State on October 28, 2009. URL: http://212.45.26.46/pub/get-file.aspx? OT=DocumentFile\&PN=Doc File\&ID=7b95ca54-5132-46e6-b06f-467b294961f6\&CT=application/msword\&FN= REPORT 